\title{
Figure of community support in achieving Muhammadiyah school autonomy progress
}

\author{
Mohamad Joko Susilo ${ }^{\text {, Badrun Kartowagiran }}{ }^{2}$, Dwi Sulisworo ${ }^{3}$ \\ ${ }^{1}$ Department of Biology Education, Teacher Training and Education Faculty, Universitas Ahmad Dahlan, Indonesia \\ ${ }^{2}$ Department of Research and Education Evaluation, Yogyakarta State University, Indonesia \\ ${ }^{3}$ Graduate Program, Universitas Ahmad Dahlan, Indonesia
}

\begin{tabular}{|c|c|}
\hline Article Info & ABSTRACT \\
\hline Article history: & \multirow{9}{*}{$\begin{array}{l}\text { School autonomy can not be separated from support factor. This study aimed } \\
\text { to determine source and form of community support and contribution in } \\
\text { realizing autonomous in Muhammadiyah schools. This research development } \\
\text { is part of dissertation conducted with five stages: define, design, model } \\
\text { development, model validation, and model use. The study was conducted at } \\
\text { SMP Muhammadiyah, Sleman Regency, with } 280 \text { respondents; consist of } \\
\text { principals, teachers, staff, students, and ministerial assemblies of Dikdasmen. } \\
\text { Data collection technique used: interviews, questionnaires, and } \\
\text { documentation. Data analysis techniques use quantitative inferential analysis, } \\
\text { EFA and CFA techniques. The results showed that form and source of } \\
\text { support for Muhammadiyah schools is internal as well as external. School } \\
\text { support also comes from internal and external support, such as: committee, } \\
\text { parents, stakeholders, foundation, education official, collages, and related } \\
\text { institutions. Directly and indirectly effect, contribution of school supporting } \\
\text { component (Bac) to be school autonomous (Kms) up to } 0.30 \text {. }\end{array}$} \\
\hline Received Aug 18, 2018 & \\
\hline Revised Okt 20, 2018 & \\
\hline Accepted Nov 5, 2018 & \\
\hline Autonomy & \\
\hline Community support & \\
\hline Muhammadiyah & \\
\hline Progress & \\
\hline School & \\
\hline
\end{tabular}

Copyright $(2019$ Institute of Advanced Engineering and Science. All rights reserved.

\section{Corresponding Author:}

Mohamad Joko Susilo, Department of Biology Education, Ahmad Dahlan University, Kampus 4 UAD, J1. Tamanan, Ringroad Selatan, Banguntapan, Bantul, Yogyakarta, Indonesia. Email: Jokoms.uad@gmail.com

\section{INTRODUCTION}

A school is undeniably able to stand up without any internal and external community support, even though school is said to have had a very strong level of autonomy. Therefore, the school also can not follow his ideas, but the idea is also part of the aspirations of society that must be realized. Given that the school is an integral part of society, which comes from community and for community, it is actually people who have the right to own and manage the school.

To build an effective and autonomous school needs to involve community participation [1]. School autonomy is school's ability to exercise authority given by central government and independently controls the bureaucracy, and decentralization in policy-making by the school itself. This allows schools to make operational school policies that involve an active role for parents, community support, or from other institutions, as well as schools more freely in organizing school operations and work [2].

In the guidance of Directorate General of High School Development, it is explained that in implementation of Independent School/National Standards School (SKM/SSN) requires readiness of all school residents, which are manifested in form of support. In addition, in implementation, it needs to get support from school related parties. That support is indispensable, as SKM/SSN is a school quality improvement based on eight national education standards requiring cooperation with other parties. Some aspects and indicators of community support include: a) school community are willing to implement 
SKM/SSN and SKS system; b) percentage of teachers, who stated willing to implement SKM/SSN and SKS system $\geq 90 \%$; c) statement of academic administration staff willing to implement SKM/SSN and SKS system; d) teachers and staffs have ability to operate computers; 5) support from school committee; e) support from parents; f) support from Provincial and Regency/City Education Offices in writing; g) support from Higher Education, LPMP/P4TK/PPPG in the context of mentoring and guiding independent school development process (preparation, implementation and evaluation); h) support of professional associations, non-structural organizations (MKKS, MGMP, Board of Education, and other educational institutions) in the process of developing and implementing SKM/SSN [3].

This important role of community support has been described in the Law of the Republic of Indonesia Number 20 Year 2003 on National Education System, Chapter XV Article 54, that: 1) community participation in education includes participation of individuals, groups, families, professional organizations, and community organizations in provision and quality control of education services; 2) communities can participate as implementing sources and users of educational outcomes [4].

Community is a major component of implementation educational process. Community contribution in school environment is also an important component for realization of school autonomy. Therefore, community support needs to be optimized as a form of participation to improve schools quality. According to Normina [5], community sympathy will grow through school efforts in incentive and proactive relationships in addition to building image of a good educational institution. Through inputs initiated from planning, implementation, monitoring, and assessment/evaluation in implementation of program, community can contribute to school.

The result, if relationship between school and community is well established, community will put full trust in the school, they will be much more sympathetic and open, and school will also easily get maximum support and assistance from community for improvement of school programs. Given participation of community does not arise by itself; school should strive to always proactive to establish a harmonious and synergistic cooperation with community. Especially in developing countries, awareness of importance education is still not fully understood that education is a shared responsibility.

So far, understanding of community participation is generally limited to support in form of education donation fund. In fact, their role is not only the funds, but community is entitled to give aspirations, ideas, creativity to develop, services, donate their knowledge, even moral. Community support can be divided into 4 categories: 1) emotional support, in form of appreciation, affection, trust, attention and willingness; 2) appraisal support, in form of approval, feedback, comparing positively, 3) informational support, in form of advice, advice, guidance, and information; and 4) instrumental support, in form of various kinds of real assistance both morale and material like money, energy, time [6], [7].

Community support can come from school committees, whose members consist of teachers, community representatives, and community leaders to give consideration to schools in managing educational institutions [8], [9]. In addition to school committees, there are community institutional roles such as: a) the community, aiming to help improve the quality of learning; b) DUDI (business and work world), supporting extracurricular activities and developing school infrastructure; c) alumni, assisting the development of school infrastructure, d) other institutions, as resource persons for student learning and funding for extracurricular school activities [10].

School relationships with community are important to do. It aims to: a) promote the importance of schooling for community; b) obtain necessary moral and financial support for school development; c) inform community about core and implementation of school program; 4) enrich or expand the school program as needed community, d) developing closer cooperation between family and school in educating children, e) maintaining school survival, f) improving school quality, g) expediting the learning process [7], [11]-[13].

The involvement of parents and community in school program aims to: a) promote quality of learning and growth of learners, b) strengthen objectives and improve quality of life and livelihood of society, c) encourage community to establish relationships with schools [14]. In the other hand, communitybased education funds can be sourced from organization, community, central government, local government and other sources. Likewise, community-based educational institutions can obtain equitable technical assistance, subsidies, and other resources from central and regional governments [5], [15].

Because of importance of role and community support, it is necessary to know how much contribution/influence of support for realization of school autonomy. This study aims to determine source and form of community support and contribution of support component on the realization of Muhammadiyah school autonomy.

Figure of community support in achieving muhammadiyah school autonomy... (Mohamad Joko Susilo) 


\section{RESEARCH METHOD}

This study is part of a dissertation using development and development research (DDR) [16] and spiral model [17]. The stages of this research consist of: 1) define, including: collecting information on relevant research results, reviewing literature, and observation; 2) design, including preparation of construct theory and model design; 3) model development and model validation, including model development and instrument making, validation model from expert judgment and preliminary testing and 4) model use is an operational field.

The research was conducted in SMP Muhammadiyah 1 Gamping, SMP Muhammadiyah 1 Minggir, SMP Muhammadiyah 2 Kalasan, and SMP Muhammadiyah 3 Depok. The subjects were 280 respondents consisting of: 4 principals, 80 teachers, 30 staff, 160 students, and 6 ministerial assemblies of Dikdasmen. Data collection techniques used: interviews, questionnaires, and documentation. Data analysis techniques used quantitative inferential analysis, EFA (Exploratory Factor Analysis) techniques to analyze instrument validity, and CFA (Confirmatory Factor Analysis) techniques to analyze fit models with Lisrel program version 8.80 .

\section{RESULTS AND DISCUSSION}

\subsection{Contribution / influence of support components to realization of school autonomy}

The constituent constructs of school support component consist of 3 main sub-components, namely: source of support, form of external support, and form of internal support. Moreover it can be presented in Table 1.

Table 1. Construct theory of school support components (Bac)

\begin{tabular}{ll}
\hline \multicolumn{1}{c}{ Sub-components } & \multicolumn{1}{c}{ Indicators } \\
\hline Support source (Sd) & External sources \\
Forms external support (De) & Internal sources \\
Forms internal support (Di) & Internal support support \\
\hline
\end{tabular}

Instruments of theoretical constructs were tested using confimatory factor analysis (CFA) method of backing component ("Bac"). Test results can be seen in Figure 1 below

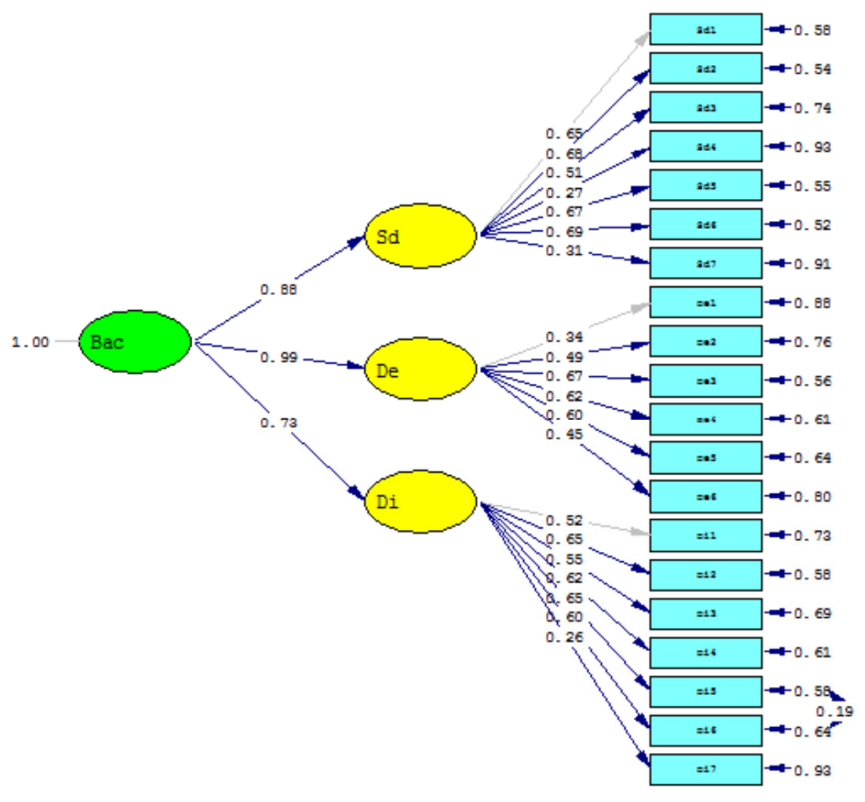

Chi-9quare $=177.03, d f=166, p-v a 1 u e=0.26470$, RMSEA $=0.021$

Figure 1. Model standardized solution school support components

Int. J. Eval. \& Res. Educ Vol. 8, No. 1, March 2019: 20 - 28 
From Figure 1 it can be seen that result of Chi square analysis $\left(\chi^{2}\right)$ has obtained standard $(177.03<2$ $(166))$, probability $\chi^{2}$ has obtained requisite that is greater than 0.05 ( $p$-value $=0.26470$ ), and RMSEA $(0,021)$ also smaller than 0.08 . Further analysis, $t$ test (t-values) indicates that all indicators for all sub components and all subcomponents of the component have obtained criteria of significance $(t>1.96)$. The results can be seen from Figure 2.

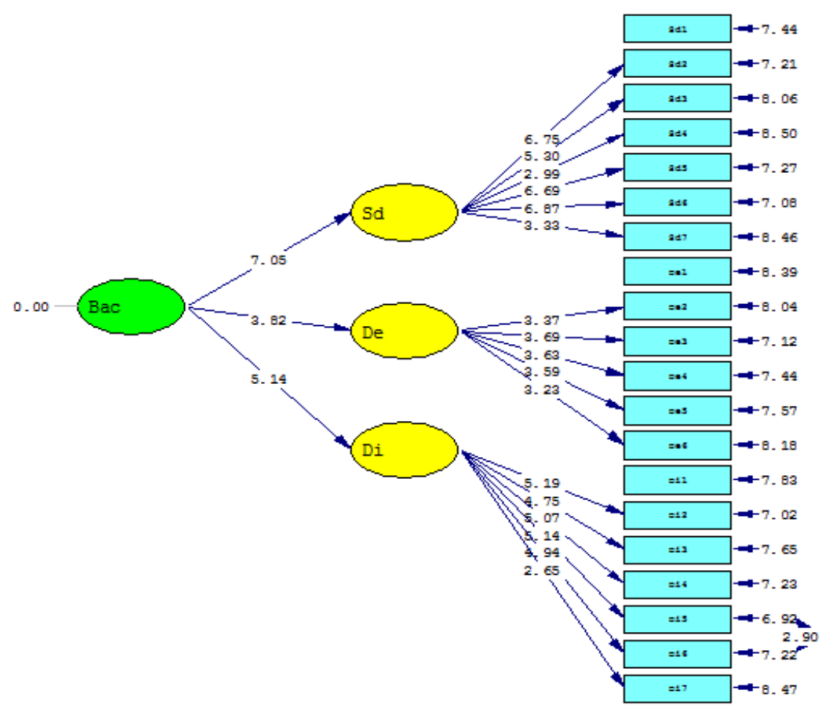

Chi-9quare $=177.03, d f=166, P-v a l u e=0.26470$, RMSEA $=0.022$

Figure 2. Conceptual model relationships on school support components

Based on Figure 2, it can be said that model has obtained goodness of fit statistics. Thus, the influence of support/backing component (Bac) on school autonomy is considered fit. The last step is to test the whole model using SEM (Structural Equation Modeling) method as Figure 3 below.

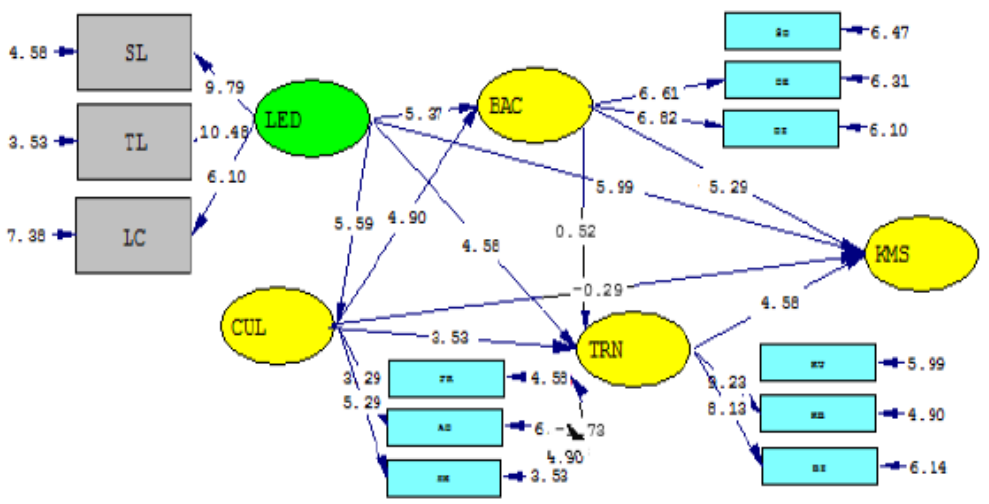

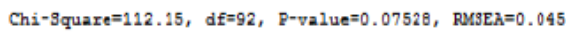

Figure 1. Result (t-value) influence of support component (Bac) on school autonomy (Kms)

The result of SEM test as in Figure 3 can be seen that value of chi square $\left(\chi^{2}\right) 112.15<2$ (92), probability value $\chi 2$ satisfies criterion greater than $0.05(\mathrm{p}=0.07528)$, root mean square error of approximation less than 0,08 (RMSEA $=0,045)$, and $t$ ( $t$-values) indicates that all components have obtained criteria of significance $(\mathrm{t}>1.96)$. Based on test results, direct the influence of school support component

Figure of community support in achieving muhammadiyah school autonomy... (Mohamad Joko Susilo) 
(Bac) on school implementation (Trn) contributed 0.002. While directly or indirectly, the influence of school support component (Bac) on realization of school self-sufficiency (Kms) contributed by 0.30 .

Backing component (Bac) is part of an endogenous variable that cannot be eliminated. This component shows how much the school's ability to build support-oriented towards realization of school autonomy, both internally and externally.

\subsection{Sources and forms of support in muhammadiyah schools}

Based on the observation by examining school documents in form of profiles, school resources, achievements of school achievement and also interview with headmaster at SMP Muhammadiyah 1 Minggir, obtained data that school community united with persyarikatan. The community conveyed idea of procuring school buses to pick up students for free, given geographical conditions of existing schools on the border of DIY with Central Java. Then, school approved and realized the idea. As a result, schools are more trusted by public and public interest is increasing rapidly from one rombel to seven rombels per force. In addition, form of support to schools that concrete and real also in form of borrowing certificates, money, and the ability of Islamic negotiations.

On the other hand, in SMP Muhammadiyah 3 Depok, there are overseas network program to get support from campus of Ahmad Dahlan University, Committee, and student guardian. The result is a lot of achievement at the international level. In SMP Muhammadiyah 1 Gamping through the program of training students' life skills such as sewing and cooking also get full support from the guardians and the community. Agreeing with the program, school is trying to accommodate aspirations of community towards their children in order to have additional skills from school.

The progress of a school that is oriented towards the realization of autonomy can not be separated from the support. School support can be categorized into five categories: 1) supporting inputs, consisting of parent and community support, support from education system, and support of adequate teaching materials (including: frequency and accuracy of teachers developing activities, sufficient number of materials and materials and adequate facilities, 2) enabling conditions, in form of effective leadership, skills of educators, flexibility and autonomy, and maximal learning time in school; 3) school climate, high student expectations, positive attitude of teachers, discipline and discipline, curriculum organization, and appreciation and motivation; 4) teaching learning process, in form of maximal learning time, various teaching strategies, frequency of providing homework, and frequency in assessing students and providing feedback; and 5) student outcomes, in form of participation, academic achievement, social skills, and economic success [13], [18].

Support itself a variety of sources and form. Source of support can come from both internal and external, while the form of support can be either immaterial or material. The source of school internal support encompasses the entire life of educational institutions, both school leaders and all members, while the source of external school support consists of elements outside school institutions, such as committees, parents, and the general public. Utilization of school support properly can be a chance of success of a school, on the contrary if the existence of various parties become obstacles of school development hence means existence of school support become threat [19]. For example, stakeholder participation in SMPN 4 Bojonegoro is ranging from planning, implementation, evaluation, and utilization of Adiwiyata program. As a result, the program is implemented in accordance with the planned [20]. Conversely, support becomes a threat e.g. the availability of internet networks in schools, but still not fully utilized to support learning [21]. Inhibiting factors of implementation of other public relations programs is the ability of users of public relations media who have not been competent in using various informations which are presented by the public relations department. For example, the limited willingness and ability of parents in using media website as one of public relations media [22].

The school's internal support such as great teacher support is associated with student support and opportunities for autonomy. Academic achievement is also related to teacher support and opportunities for autonomy [23]. Support facilities can also affect the achievement of learning and success in providing the best service for students [24], [25]. The support of information and communication technology (ICT) facilities in learning can enrich the repertoire of scientific knowledge, increase the source of infinite study, increase learning motivation, improve learning outcomes, and efficiency of time and place [26]. In addition, through the support of android-based technology in learning can improve the ability to think critically, creatively, science process skills, learning outcomes, and students' scientific attitudes [21], [27]-[29].

External support from parents to students in achievement is also an important part of the school. Social support from family has a greater role to achieve student achievement than social support from teachers and friends [30]. This family support also plays a major role in formation of a child's soul, even his career in the future [31]. Social support from families, peers and teachers as an influence on student

Int. J. Eval. \& Res. Educ Vol. 8, No. 1, March 2019: 20 - 28 
engagement, academic success, and satisfaction with school [32]. The support of parents who are involved in their children's educational development [33].

Generally, Muhammadiyah schools have internal support such as: quality resources; sources of funds derived from BOS [34], SPP, and other support; close and compact relationships among the community of school[35]. Strong external support also comes from: committees, communities, parents/guardians; support from stakeholders, from foundation, the ministerial assembly of dikdasmen, provincial Muhammadiyah leaders, education offices, consultants, universities, other schools, and related institutions [35]-[37]. In addition, many Muhammadiyah schools are also standing on wakaf land that has been handed over to assembly [38]-[42]

As for funding, so far Muhammadiyah schools still use the main funding source of student guardian contribution (SPP). There are also other sources of funds from the government/foundation. In addition, most schools have also implemented self-sufficiency in funding, by managing BUMS (School Owned Enterprises), which vary from one school to another. For example SD Muhammadiyah Sapen who has established a school-owned enterprise in field of catering with SBM (Sapen Boga Mandiri), after one year earlier successfully opened convection service[43], SD Muhammadiyah Bausasran 2 with school canteen empowerment can produce income generating up to two millions per month, SMP Muhammadiyah 2 Kota Yogyakarta with mini market and school cafeteria [44] can bring income generating school reaching number four million per month. In addition, there is a cross subsidy payment system, loyal fundraising of friends, as well as transparent and accountable fund management.

As a form of feedback from schools to their school community, Muhammadiyah schools also gave appreciation. Generally, appreciation is a scholarship or reward to teachers, employees, and learners. In SMP Muhammadiyah 1 Minggir, teachers and employees whose school at the school must open an account on behalf of his son. Such accounts are used in order to receive payment or award of student achievement. Students belonging to following categories also get scholarship achievements given in form of bank savings, among others: a) students achieving first place in elementary school/MI when accepted at SMP Muhammadiyah 1 Minggir; b) SHUSD's first rank student; c) Students who are the first winners of each semester in their grade; d) Students who excel at the $1^{\text {st }}$ winner until $5^{\text {th }}$ get scholarship worth Rp. 1.500.000,00; and e) students who excel memorize Qur'an every one juz get scholarship RP 1,000,000.00 in form of cash given at parent guardian meeting one year 2 times.

The school's appreciation is part of school's strategy to improve achievement spirit of all school residents. Of course, every strategy requires strong readiness and support, both in terms of funding, facilities, cohesiveness, and active participation from all sides. As is done in Muhammadiyah Manyar Gersik and Muhammadiyah 2 Pontianak Elementary School, implement participatory strategy and accuracy in formulating good planning to attract public interest. The result, rapid progress achieved by school [45], [46]. In Islamic junior high school AL-Azhar 14 Semarang has also succeeded in building a harmonious relationship between school and community through public relations programs internally and externally. The internal program is directed to build harmonious relationships between internal institutions, while external programs are directed to build a positive public image of institution through various development activities of teachers, religious development, cooperation with various parties and improving quality of learning activities undertaken [22]. Form of community participation to the school as happened in MIN Tegalasri is by establishment of class 'paguyuban' in each class. The role of classroom community is, among others, core teacher, learning resource, providing inputs on school tutoring, assisting commemoration of Islamic day (PHBI) at school; become subject of skill subjects, give inputs in the preparation of budget and expenditure budget plan (RAPBS) every year, become organizer of deepening activities for class VI, school together committee to make school development plan (RPS) and RAPBS, preparing teaching and learning activities in schools as well as helping funds, personnel, materials and thoughts in school activities [47].

Basically, school support is not only material, schools also require intervention and innovation in terms of learning from other parties, for example from universities especially Teachers Training Institute (LPTK) and stakeholders [48]. Parental support to students in achievement is also an important part of school. Social support of this family is greater in its role in achieving student achievement than social support of teachers and friends [30]. Family support also plays a major role in formation of a child's soul, even his career in future [31]. Not only that, support of facilities also affect achievement of learning and success in providing the best service for students[24], [25]. So, to be able to reach school in advance of school must already have independence, and independence of a school cannot be separated from support factor. This support is a direct appreciation through school community (internal), as well as through society (external support).

Although a school has been predicated as school autonomy, the school cannot be said to be fully independent, but relative [49]. It is because to be self-sufficient schools need to get support from all school community, assembly dikdasmen, committee, and wider community. Schools are said to have autonomy in

Figure of community support in achieving muhammadiyah school autonomy... (Mohamad Joko Susilo) 
support if they have: a source of support, internal support, and external support [50]. The purpose of support is to disseminate information about school development and to obtain assistance both morally and materially in developing excellent programs and improving school quality [51], [52]. In addition, learning support assisted in meeting learners' academics, social and emotional needs by addressing barriers to learning, creating conducive learning environments, enhancing learners' self-esteem and improving learners' academic performance [53].

Thus, to reduce the constraints that need to be effective education planning, management of educational institutions should be done thoroughly starting from integration of curriculum management, human resources, infrastructure, financing, public relations and marketing, and other aspects [54]. As a form of realization can be done through: a) giving awards to citizens of school as conducted in SMP Muhammadiyah 1 Minggir; b) improving professionalism of educators and education personnel e.g. through ICT training [55]; c) supervise learning; d) provide appropriate facilities and infrastructure; e) as well as applying model of improving quality of education toward schools autonomy that are progressing [56].

\section{CONCLUSION}

Based on the results of research can be concluded that: 1) the form and source of support for Muhammadiyah schools in form of internal support, such as qualified resources, sources of funding from various parties, and warm relationships among school members. External support also comes from: committee, community, parent/guardian; support from stakeholders, from foundation, Dikdasmen assembly, provincial Muhammadiyah provincial leadership, education office, consultant, college, other schools, and related institutions. 2) The direct impact of school support component (Bac) on school implementation (Trn) contributed to 0.002 . While directly or indirectly, influence of school support components (Bac) on the realization of school autonomy (Kms) contributed by 0.30 .

\section{REFERENCES}

[1] Raharja S. Parent participation in school management: A multicultural education perspective. Manaj Pendidik. 2011;1(VII):93-108.

[2] Scileanna A. Advancing school autonomy in the Irish school system. Oideachais; 2015.

[3] Directorate General of High School Development. The concept of a school category independent/school national category (SKM/SSN). Jakarta: Ministry of Education; 2008.

[4] Law of the Republic of Indonesia Number 20. National Education System. Jakarta; 2003 p. 20.

[5] Normina. Community participation in education. Ittihad J Kopertais Wil XI Kalimantan. 2016;14(26):71-85.

[6] Cohen S, Syme, Leonard S. Social support and health. Florida: Academic Press; 1985.

[7] Valli L, Stefanski A, Jacobson R. Leadership in school-community partnerships. Procedia - Soc Behav Sci. 2014;141(August 2014):110-4.

[8] Raihani. Education reforms in Indonesia in the twenty first century. Int Educ J. 2007;8(1):172-83.

[9] Siswanto, Suyatmini, Sutrisna B. Management of 1 SMP Negeri 1 Simo in the apbd mechanism of Boyolali district government in 2011. J Manaj Pendidik. 2014;9(2):196-200.

[10] Sulistyorini. Community participation in the development of elementary schools. J Pendidik dan Pembelajaran. 2011;18(2):180-7.

[11] Umiarso, Imam G. Quality management of schools in the era of educational autonomy: Towards education with a quality control approach for actors in educational institutions. Yogyakarta: IRCiSoD; 2011.

[12] Mulyono. Administrative management and educational organizations. Yogyakarta: Ar-Ruzz Media; 2008.

[13] Gross JMS, Haines SJ, Hill C, Francis GL, Blue-Banning M, Turnbull AP. Strong school-community partnerships in inclusive schools are "part of the fabric of the school....we count on." Sch Community J. 2015;25(2):9-34.

[14] Mulyasa. Principal management and leadership. Jakarta: Bumi Aksara; 2011.

[15] Basri AH. Capita as selective as education. Bandung: CV. Pustaka Setia; 2012.

[16] Richey RC, Klein JD. Design and Development Research. 10th ed. Akers LMA, editor. Mahwah, New Jersey: Lawrence Erlbaum Associates; 2007. 180 p.

[17] Cennamo K, Kalk D. Real world instructional design. Wadsworth: Wadsworth/Thomson Learning; 2005.300 p.

[18] Heneveld W. Planning and monitoring the quality of primary education in Sub-Saharan Africa. Washington, DC: AFTHR Technical Note No. 14.; 1994.

[19] Febriyanti A. Scanning the external and internal environment of Islamic education institutions. J Kependidikan. 2015;III(2):1-13.

[20] Aulia G. Stakeholder participation in implementing the adiwiyata program at Bojonegoro 4 Public Middle School. Kebijak dan Manaj Publik. 2016;4(3).

[21] Aminatun T, Subali B. Development of biology learning modules based on android mobile local ecosystem material area to improve thinking skills of high school students. Yogyakarta; 2016.

[22] Maskur. The importance of public relations at stakeholders of educational institutions. Wahana Akad. 2014;1(2):167-80.

Int. J. Eval. \& Res. Educ Vol. 8, No. 1, March 2019: 20 - 28 
[23] Rodríguez MC, Vivas JR, Comesaña A, Ramírez LM, Peña JA. Perceived social support in middle school students. Int Rev Soc Sci. 2017;5(January (1)):81-90.

[24] Rahman MF. The effect of parental support and learning facilities in schools on economic learning achievement through learning motivation in the VIII junior high school class 2 Ungaran. In: Proceedings of the National Seminar on Economic and Business Education. Surakarta: Teacher Training and education Faculty of Sebelas Maret University; 2015.

[25] Bhakti CP. Availability of guidance and counseling facilities and infrastructure in secondary schools in Gunungkidul district. J Pendidik (Teori dan Prakt. 2017;2(2):100-4.

[26] Yuningsih. Application of ict in teaching through perspectives biology education lecturers. Proc 2nd Int Semin Sci Educ. 2016;2:436-41.

[27] Yuningsih. Developing android-based pbl module using analogical approach to improve senior high school student's creativity based on divergent thinking [Internet]. Yogyakarta State University; 2017. Available from: eprints.uny.ac.id/53412

[28] Dwiyani A. Development of mountain range ecosystem modules based on android mobile using PjBL model to increase the science process skills (KPS) and scientific attitudes of high school students [Internet]. Yogyakarta State University; 2017. Available from: https://eprints.uny.ac.id/47632/

[29] Meliana D. Development of an android-based biology learning module with a service learning model to improve the critical thinking skills of high school students on the subject of rice ecosystems [Internet]. Yogyakarta State University; 2017. Available from: https://eprints.uny.ac.id/53109/

[30] Wibowo MW, Susanto DY. The dynamics of social support on the achievements of elementary school students based on the indigenous psychology approach. J Psikol Tabularasa. 2014;9(1):30-6.

[31] Ningrum MA. The role of family in cultivating entrepreneurial spirit from an early age. J Pendidik. 2017;2(1):29-32.

[32] Gutiérrez M, Tomás J-M, Romero I, Barrica J-M. Perceived social support, school engagement and satisfaction with school. Rev Psicodidáctica. 2017;22(2):111-7.

[33] Mapp KL. Having their say: Parents describe why and how they are engaged in their children's learning. Sch Community J. 2003;13(1):35-64.

[34] Ahmad LMT. School operational funding to support school activities. Int J Eval Res Educ. 2014;3(1):66-78.

[35] Widiyastuti I. Implementation of education quality improvement policies at SMP Muhammadiyah 1 Depok Sleman Yogyakarta. Yogyakarta State University; 2016.

[36] PontianakPost.co.id. sd muhammadiyah 2; smp muhammadiyah 1 [Internet]. pontianakpost.co.id. 2016 [cited 2018 Apr 25]. Available from: https://www.pontianakpost.co.id/sd-muhammadiyah-2-smp-muhammadiyah-1wow

[37] Susilo MJ. Strategies for building autonomous schools. In: The Second Progressive and Fun Education Seminar. Lombok: Association of Biology Education Study Programs; 2017. p. 569-76.

[38] Asy'ari M. Problems with waqf governance in the environment of Muhammadiyah Aceh. J Ilm Islam Futur. 2016;16(1):32-51.

[39] Ghojali NA. Looking for productive Muhammadiyah endowments [Internet]. pdmjogja.org. 2015 [cited 2018 Apr 25]. Available from: https://pdmjogja.org/mencari-wakaf-produktif-muhammadiyah/

[40] Kamal MA. Muhammadiyah again received the waqf land [Internet]. Menara62.com. 2017 [cited 2018 Apr 25]. Available from: http://menara62.com/2017/01/11/muhammadiyah-kembali-terima-tanah-wakaf/

[41] Muhammadiyah Boarding School. Sejarah PPM MBS [Internet]. - Muhammadiyahboarding.sch.id. 2018 [cited 2018 Apr 25]. Available from: https://muhammadiyahboarding.sch.id/sejarah/

[42] Pwmu.co. After a 1.5 hectare grant, the Muhammadiyah is now unfortunate to accept waqf [Internet]. Pwmu.co. 2016 [cited 2018 Apr 25]. Available from: https://pwmu.co/13986/08/15/setelah-hibah-15-hektar-kinimuhammadiyah-malang-terima-wakaf/

[43] SD Muhammadiyah Sapen. Sapen launching; sapen cooks independently [Internet]. SD Muhammadiyah Sapen. 2017 [cited 2018 Apr 5]. Available from: http://www.sdmuhsapen-yog.sch.id/read/583/sapen-launching-sapenboga-mandiri.html

[44] Suara Muhammadiyah. Pay attention to the nutrition of students, junior high school Muhammadiyah 2 Yogyakarta launching mini markets and catering [Internet]. Suara Muhammadiyah. 2017 [cited 2018 Aug 16]. Available from: http://www.suaramuhammadiyah.id/2017/07/18/perhatikan-gizi-siswa-smp-muhammadiyah-2yogyakarta-launching-mini-market-dan-catering/

[45] Hidayati M. Community relations strategy in an effort to attract the interest of the Fullday school community. Inspirasi Manaj Pendidik. 2016;4(1):1-10.

[46] Zaini A, Zakso A, Syukri M. Community participation in the administration of education. J Pendidik dan Pembelajaran. 2014;3(11):1-13.

[47] Kholis N, Zamroni, Sumarno. School quality and culture of stakeholder participation (Phenomenology study at the confessional school MIN Tegalasri Wlingi Blitar. Pembang dan Pendidik Fondasi dan Apl. 2014;2(2):130 42.

[48] Haviz M. Designing and developing a new model of education surau and madrasah Minangkabau Indonesia. J Pendidik Islam. 2017;6(June):79-100.

[49] Caldwell BJ. Impact of school autonomy on student achievement in 21st century education. Vol. 30. 2014. 1171$1187 \mathrm{p}$.

[50] Susilo MJ. Development of a model for evaluating the independence of Muhammadiyah schools in Sleman Regency. Yogyakarta State University; 2017.

Figure of community support in achieving muhammadiyah school autonomy... (Mohamad Joko Susilo) 
[51] Schmelkes S. School autonomy and assessment in Mexico. Prospects. 2001;XXXI(4):575-86.

[52] Sumintono B. School capacity development approach. J Manaj Pendidik. 2013;2(1):1-19.

[53] Bojuwoye O, Moletsane M, Stofile S, Moolla N, Sylvester F. Learners' experiences of learning support in selected Western Cape schools. South African J Educ. 2014;34(15).

[54] Makruf I. Leadership model in integrated islamic educational institutions. J Pendidik Islam. 2017;6(December):331-48.

[55] Purwowidodo A. Revitalization of the role of recently madrasah teacher: Modern learning perspective and utilization of ict in the globalization era. J Pendidik Islam. 2017;6(June):169-93.

[56] Asiah S. Transformation of islamic education quality through regional autonomy in Bone Bolango regency, Gorontalo Province. J Pendidik Islam. 2017;6(June):51-78.

Int. J. Eval. \& Res. Educ Vol. 8, No. 1, March 2019: 20 - 28 